\title{
Pakistani Bureaucracy: Crisis of Governance and Prospects of Reform
}

\begin{abstract}
SAEED SHAFQAT
This paper is divided into three parts. The first part provides an overview of literature on how the role and assessment of bureaucracy in the Third World in general and Pakistan in particular has undergone change. The second part examines the changing socioeconomic profile and corresponding attitudinal changes if any, in Pakistan's bureaucracy. The third part provides guidelines for possible reform in Pakistan's federal bureaucracy.
\end{abstract}

\section{ASSESSING BUREAUCRACY: A REVIEW OF LITERATURE}

For almost two decades (i.e. 1950-1970) the academic community presented bureaucracy in the developing countries as engine of growth, development and an agent of change [Lapalambora (1963) and Apter (1967)]. Bureaucracy in Pakistan provided a lead and received laudatory comments for its role in initiating economic development and promoting political stability [Huntington (1968); Von Vorys (1965) and Braibanti (1966)]. Bureaucratic elites and public institutions were expected to provide leadership, order and stability. Again Pakistani bureaucracy stood the test and fulfilled these expectations [Huntington (1968)]. By the late 1960s that witnessed movements of popular protest and agitation against the authoritarian and repressive role of the government, the opposition political parties, and a segment of the print media started portraying the bureaucracy as an instrument of oppression. This portrayal had an impact on public consciousness. Bureaucrats were seen as being inimical to their interests. By the mid-1970s the academic community and the World Bank (both in their own wisdom and direction) began to reassess and reevaluate the role of bureaucracy [Donell (1973) and Laporte (1975)]. In the early 1980s the World Bank studies began casting aspersions on bureaucracy's ability to promote order and development in the Third World. Corruption, inefficiency, bloated size, absence of accountability, and resistance to change were portrayed as the manifestations of bureaucracy [World Bank Report (1983-1993)]. The academic community raised concerns about authoritarian values and corrupt practices that 
bureaucracies promoted in the developing countries-i.e. violation of human rights and suppression of liberties. The academic community recognised and conceded some positive contribution of bureaucracy in the direction of growth and development [Burki and Laporte (1986)]. In short negative images of bureaucracy and a cry for reform dominated the policy and academic research environment.

In 1991, three papers presented by Boeninger, Mills and Serageldin at the World Bank Conference on Development Economics brought the issue of governance to the core of the debate on institutional reform [Boeninger, LandellMills and Serageldin (1991)]. The World Bank economists conceded and recognised that governance was no longer a matter of economic development alone. There were cultural, political and institutional factors that influenced the process of governance. These studies drew attention towards the fact that good governance was a function of political will and commitment of the leadership, which in turn was affected by cultural, historical/institutional settings of a country. That external environment i.e. conditions of aid, pressures of donor agencies and international institutions also influenced styles and modes of governance. In short, public policy debate underwent a paradigm shift in which institutional reform i.e. reform of the bureaucracy, judiciary, legislatures became the cry of this decade. Thus, the World Bank, IMF and UNDP, provided the lead in initiating a dialogue on reform strategy for the bureaucracies in the Third World. Given this context, how should one assess the role of bureaucracy? What kind of leadership can it provide in managing public institutions? What type of strategies can be adopted to build an efficient bureaucracy that may promote good governance?

Bureaucracy is pivotal to modern government. This is recognised both by the proponents and the opponents of bureaucracy. In a developing country what is the primary function of bureaucracy? The answer could vary depending on the culture of a society, its level of socioeconomic development and the nature of its political system. In a traditional sense, in most political systems, bureaucracy has been expected to ensure continuity of policies, political order/stability, uphold rule of law, promote economic development and cultural cohesion. These traditional functions have been forcefully defended by the proponents of bureaucracy.

If one were to look at the performance of bureaucracy in the Third World the results are mixed. In most countries of South Asia, the authority and social elite status of bureaucracy is still recognised; despite erosion of power and politicisation. Its major failure is in its inability to promote welfare, development, equity and provide justice to the citizens.

Peter Drucker in a recent article "In defense of Japans Bureaucracy" makes a strong case for elitism and continuity as hallmarks of a strong bureaucracy [Drucker (1998)]. Elites of merit and function if respected in a society, as the Japanese case demonstrates, do promote continuity and cohesion. Drucker argues that the Japanese bureaucracy has performed these two tasks ably, despite other serious problems. 
Furthermore, Drucker asserts that in most developed countries, "Bureaucracy dominates policy-making process. America and few European countries are an exception” [Drucker (1998)]. This leads him to conclude that the:

bureaucratic elites have far greater staying power then we are willing to concede. They manage to keep power for decades despite scandals and proven incompetence.

He hastens to add, that without ruling elites most developed countries fear social disintegration. It is this "staying power" that sustains continuity and enhances the enduring capacity of bureaucracy. In the case of Japan, Drucker argues it has worked well because it keeps the society integrated. The Japanese feel that their society is fragile. Therefore bureaucracy as a ruling elite is considered essential to ensure cohesion.

Drucker is so convinced of elitism and continuity as an enduring aspect of bureaucracy as to assert that in some societies and situations "procrastination" was wiser than action. To what degree the experience and functioning of Japan's bureaucracy is relevant to Pakistan? It cannot be denied that very much like Japan, Pakistani society does give credence and legitimacy to its elites.

Broadly speaking in our context, the elites can be divided into two categories i.e. elites of ascription - who enjoy position of power, privilege and prestige on the basis of their descent, family, social class etc. Second, the elites of merit, achievement and excellence. The latter enjoy a position of power, privilege and prestige on the basis of education and professionalism. In most societies the relationship between elites of ascription and those of achievement is complex and Pakistan is no exception. In most developing societies the size of elites of merit and achievement is small (although it is growing) and social class origins can be an advantage for some and disadvantagious for others. The gulf widens because equal opportunity of education is not available to all. Thus a symbiosis between ascription and achievement is pronounced. On occasions in Pakistani context, it becomes difficult to draw a distinction between the two types of elites. The newspaper reports and popular writings have considerably blurred this distinction. Consequently, the elites of merit and achievement have to struggle constantly to acquire legitimacy. It is worth noting that in our case bureaucracy, (despite limitations and failures) has been performing the task of ensuring continuity in policies. Secondly, despite frequent and sometimes sudden changes of governments Pakistani bureaucracy continues to manifest considerable "staying power" notwithstanding the charges of corruption and inefficiency.

A certain degree of cohesion, staying power, organisational capacity to sustain continuity of policies, preserve the status quo and maintain a semblance of stability continue to be the hallmarks of Pakistani bureaucracy. Is it possible to bring out any attitudinal and structural changes in the Pakistani bureaucracy? 
According to Osborne and Plastrick, the new gurus and out-spoken advocates of Banishing Bureaucracy and Reinventing Government [Obsorne and Plastrick (1996), Obsorne and Baebler (1993)], there is a need to redesign the "DNA" of bureaucracy. The two argue that bureaucracy must be changed and restructured from within. This would be accomplished by adopting the following strategy:

- To restructure public organisations to redefine their purposes.

- Enhance accountability.

- Provide incentives.

- Re-organise distribution of power, and most importantly.

- Change their cultures.

What is important to recognise is that the traditional concept of governance (i.e. hierarchical, authoritarian, and emphasising chain of command) is under-going a change. Instead, Osborne and Plastrick argue that reinvention is possible only through "collaboration between elected official and the civil servant". They also recognise that public institutions were "designed to be stable", but hasten to add that:

we have reached a point in history where stability is counter productive. In today's fast changing, globally competitive information age, systems that cannot change are doomed to failure. They are like the dinosaurs, which could not evolve fast enough to survive when their environment changed.

This observation is pertinent because it clearly suggests that bureaucratic stability without adaptability and capacity to innovate is meaningless and self-destructive.

It appears to me that Osborne and Plastrick are not advocating elimination of bureaucracies, they are only "Whistle blowing"-i.e., if the bureaucracies do not mend their ways they would face extinction like "dinosaurs". The warning is timely, as it has not only intensified debate on the degree and shape of bureaucracy in a modern state but also provided tools and ideas through which public institutions may be reinvigorated and strengthened.

There is a growing consensus among policy-makers, intellectuals and international institutions that effective public institutions are essential for smooth functioning of the state [World Bank Report (1997); Osborne and Plastrick (1996); Turner and David Hulme (1997)]. This realisation is also growing that whereas expansion and strengthening of civil society is a desirable goal non-governmental organisations (NGOs) are no substitute for the government. Therefore public institutions and bureaucracy are crucial components for good governance. The challenge for the state is to reform and rebuild the public institutions that would be competitive, enterprising and capable of upholding the rule of law. Thus reform in civil service demands prudence and caution. Laws and procedures should be adopted through transparent mechanisms, so that they promote merit, fairplay and 
accountability among public officials. Clearly, strengthening bureaucracy does not mean preserving the status quo, it implies building the capacity to initiate change and manage it effectively. The World Bank Report 1997, correctly states that:

Once poor systems are in place, they can be very difficult to dislodge.

Strong interests develop to maintain the status quo, however inefficient or unfair. And those who lose out from present arrangements may be able to bring effective pressure to bear for change.

In such circumstances public institutions become not only resisters of change and innovation but also develop into instruments of repression, partisanship and are portrayed as corrupt, unjust and inefficient. It is these images and perceptions that evoke criticism from the opponents of bureaucracy-who demand reform and innovation in the workings of public institutions.

The foregoing review of literature captures the debate on the centrality of bureaucracy, its staying power, elite status, capacity to sustain, continuity of policies and its reluctance to change giving rise to demands for reform and innovation in its functioning. The challenge is: how to build a bureaucracy that is efficient, humane, development-driven, is citizen-friendly and facilitates good governance and human development.

In view of the changing socioeconomic profile of Pakistani bureaucracy, the demands for reform and the changes it has undergone as a result of this reform effort we may ask whether the reorientation of bureaucracy is a desirable goal?

\section{DO CHANGES IN SOCIOECONOMIC PROFILE PROMOTE ATTITUDINAL CHANGE?}

Pakistan had a small bureaucracy at the time of independence. However in the past five decades it has grown and expanded and become a fairly large and amorphous lot. Federal government employs over 5 lakh civil servants. Out this 90 percent are between Grade 1-15, while 10 percent are in Grades 16-22. Of these the CSS officers comprise around 5 percent. The focus of attention and analysis in this section are these powerful privileged and prestigious elites.

In the past five decades the structure of the civil services has undergone enormous transformation. If one were to take the socioeconomic status (SES) and education as two variables, those who joined the civil services during the decade of 1950 to 1960s, almost 70 percent came from the middle class, about 25 percent belonged to the upper class, while those from the lower middle class were around 5 percent. About 60 to 65 percent had done M.A./M.Sc and 40 to 45 percent were simple B.A/B.Sc. The average age of a new entrant to the service was 22-23 years [Ahmad (1964) and Braibanti (1966)]. Has this profile undergone any change? Statistics for the decade 1987-97 reveal that almost 88 percent describe themselves belonging to the middle class, while 4 percent belong to the upper class, and 8 percent to the lower 
class. About 75 percent have M.A/M.Sc degrees (including 20 to 30 percent doctors and engineers) the percentage of simple graduates has declined to about 25 percent. The average age of a new entrant to the service is $27-28$ years (See Table 1 ).

Table 1

\begin{tabular}{lclc}
\hline Years & SES (\%) & Education (\%) & Av. Age (Yr) \\
\hline $1950-1960$ & $5 \mathrm{LC}$ & $60 \mathrm{MA} / \mathrm{MSc}$ & $22-23$ \\
& $70 \mathrm{MC}$ & $40 \mathrm{BA} / \mathrm{BSc}$ & \\
& $25 \mathrm{UC}$ & & \\
$1987-1997$ & $8 \mathrm{LC}$ & $75 \mathrm{MA} / \mathrm{MSc}^{*}$ & $27-28$ \\
& $88 \mathrm{MC}$ & $25 \mathrm{BA} / \mathrm{BSc}$ & \\
& $4 \mathrm{UC}$ & & \\
\hline
\end{tabular}

SES = Socioeconomic Skills (Lower class, Middle class, Upper class).

* (includes doctors, engineers).

Furthermore, a substantial number joining the Civil Services hail from the urban middle classes. The Common Training Programme (CTP) data indicates that from the 1st CTP to 22nd CTP (1973-1995) a total of 3,374 officers joined the twelve federal services of Pakistan. Among these, the most prominent are the children of the government servants (900) (i.e. sons/daughters of a clerk to a high ranking officer) the second largest group is that of the offsprings of professionals (515) (Doctors, Engineers, Lawyers), followed by Agriculturalist/landlords (514) and businessmen (406). The number of children of the Civil Servants (i.e. CSS Officers) is (167) and that of Defence Forces Officers (165).

Beside these other social and occupational groups in the society are also adequately represented in the higher civil services (See Table 2). These groups,

Table 2

Composition of CSS Officers Background [Data Based on Forms from (1973 to 1995)]

\begin{tabular}{clcc}
\hline Ranking & \multicolumn{1}{c}{ Background } & Numbers (3374) & \% of Total \\
\hline 1. & Children of Govt. Servants & 900 & $27.6 \%$ \\
2. & Children of Professionals & 515 & $15.2 \%$ \\
3. & Children of Agriculturist/ Landlords & 514 & $15.2 \%$ \\
4. & Children of Businessmen & 406 & $12 . \%$ \\
5. & Children of Civil Servants (CSS) & 167 & $5 \%$ \\
6. & Children of Defence Forces & 165 & $5 \%$ \\
7. & Children of Farmers/Zamindars & 277 & $6.7 \%$ \\
8. & Children of Shopkeeper/Trader Merchant & 77 & $2.2 \%$ \\
9. & Industrialist/Private Sector & 51 & $1.5 \%$ \\
10. & Others & 352 & $10.6 \%$ \\
\hline
\end{tabular}

Source: Compiled by Saeed Shafqat. 
collectively constitute about 10 percent of the total CSS services. It is a myth that civil servants and their progenies have a monopoly in the services as some newspaper reports tend to convey. The data clearly demonstrates that since the children of the government servants, professionals, business groups, agriculturists/ landlords, civil servants and defence officers have better access to education they take and qualify the examination in larger numbers, therefore their dominance is visible. It is again understandable that as compared to other social groups, since these groups are more knowledgeable about patterns of authority and status associated with various groups (i.e. DMG, Police, Customs, Income Tax), therefore in identifying their service/group preference they are better informed at the time of going through the CSS examination process.

Occasionally it does happen that despite attaining higher merit in the examination, a candidate ends up in a service that does not correspond with his/her merit position. This happens because of lack of information about the rankings of various service/groups in the structure of the government. In this sense the sons/daughters of civil servants have a definite advantage; they chose and join services and groups that enjoy power, authority and elite status. Therefore upon joining the service, despite being smaller in number they are more visible. This happens because of two reasons. First, their parents may have held prominent appointment as civil servants. Second, in our society where status is determined by lineage, achievement is down played. This is newsworthy and promotes a public image that parental connections compromised merit.

It is equally important to note that each year 1 to 5 cases of children of the under privileged class (a daily wage labourer, taxi driver, a peasant, petty clerk, shop keeper) have on the basis of competition, hard work and ability to excel entered the service lending legitimacy and credibility to the Federal Public Service Commission (FPSC) examination process, although in recent years the interviewing process and composition of the FPSC has come under criticism from various groups.

The change is visible and pronounced. The new breed of entrants to the Civil Services is older, predominantly middle class and have a much more diversified educational background. Education and social class are two indicators that give credence to dynamic and modernist potential of the Civil Services of Pakistan.

Given this social class and educational background, in their attitude, these new entrants to the civil services are politicised, pragmatic, adaptable, conscious of power and authority that is vested in them. They also recognise the social utility of greed that is prevalent in the society. Upon joining the civil services a substantial number still cherish the ideals of honesty, integrity, public good and service to the nation. Yet they are conscious of the fact that upon selection to the civil services, they have become members of an "elite governmental club". They argue, that it is the civil society which bestows status upon them, develops unreal expectations and 
encourages them to behave like a person who commands authority in public perception. This public perception plays an important role in attitude formation and influencing the conduct and behaviour of civil servants.

While choosing a particular service the new entrants have the following considerations.

- What are the prospects of promotion in a particular occupational group?

- What type of legitimate perks and privileges are available?

- What is the culture of the service like-i.e. degree of 'esprit de corps', prospects of horizontal mobility etc?

- How much symbolic value an occupational group has? This consideration is influenced by public perception and premium.

- Finally, besides authority, prospects of making easy money is another important consideration. Are these considerations any different from those which were prevalent during the 1950s and 1960s? Is it a change in societal values or individual civil servant who has become morally bankrupt?

Decline theorists insist that educational standard and quality of individuals joining the civil services is inferior if not poor as compared to what it was in 1950s and 1960s. In the eyes of the critics the structure of the services remains 'colonial' and 'transformation' has been 'cosmetic'. In their perception civil servants remain arrogant, corrupt, over-bearing, inefficient and self-perpetuating [Mufti (1998) and Siddique (1999)]. They allege the structure of civil services is tottering apart, they are on the decline, and they warn as we move towards the 21st century, the civil services are ill equipped to govern or serve the people or meet the challenges that confront the country. This criticism merits attention.

Recognising the concerns of the critics, it is contended that the Civil Services of Pakistan have come a long way. They have revealed the capacity to adapt, according to changing needs and political environment of the country. The service structure has become broad, relatively open and competitive. According to Federal Public Service Commission (FPSC) each year about 8000 persons apply for the CSS examination (Estimates of (1991-1997), about 3,000 actually take the examination, 600 to 800 pass the written examination and depending on the vacancies available with the federal government in the 12 Federal Services, 170 to 200 are finally selected. Secondly, more senior positions are available to different occupational groups, although dominance of the Civil Services of Pakistan (CSP) is visible at the policy-making level—both in the federal and provincial governments.

An overview of 50 years of Pakistan's history would reveal the need for reforms in the civil services has been felt all along. Both civil and military regimes have ventured to change the attitude of the civil servants, reform the structure of the services to appease popular expectations, and expand their political control over bureaucracy. Most of these regimes have pursued purges and reforms as policy 
instruments to change the behaviour of civil servant and expand their own political control. Each reform effort was preceded by a purge in the Civil Services of Pakistan. President Ayub's purge was followed by the Cornellius Pay Services and Reform Commission of 1962. General Yahya's famous purge of 303 was followed by publicising the recommendations of the Cornellius Report, Zulfikar Ali Bhutto's 1973 Administrative Reforms were preceded by massive purge of about 1300 civil servants. General Zia-ul-Haq's government was exceptional to the extent that it did not pursue any systematic purge as a policy choice, but constituted the Anwar-ulHaq Commission to rehabilitate and promote some level of confidence, among the Civil Services, particularly the CSP. In addition, it did what none of the earlier purges and reforms had none-it embarked upon a policy to redefine the ideological orientation of the civil servant by formally and informally encouraging a uniform dress code, a culture of prayer-break during office hours, with minimal emphasis on professional work ethics. Furthermore, the Zia-ul-Haq government expanded and institutionalised the induction of armed forces personnel into civil services. Zia-ulHaq instituted a 20 percent quota in the Civil Services for the Armed Forces-10 percent to be recruited from grade 17 (i.e. Captain level) and other 10 percent from Major and beyond and even those who may have retired from services in the Armed Forces. Those who were inducted at the Captain level were placed in seniority above those who entered the service through merit and competition. This had a demoralising effect on the new recruitees. The cumulative effect of these measures was that the modernist, forward looking, and liberal qualities of professional competence were considerably eroded.

These purges and reforms shook the confidence of the civil servants, led to politicisation and to a certain degree encouraged an environment where financial corruption and misuse of authority proportionately increased. It is in this broader context of purge and reform that the suspension of 87 civil servants in the early 1997 and subsequent formation of a Task Force for civil service reform may be examined.

During the first decade of Pakistan's history the primary issues that attracted government's attention were rehabilitation of the migrants, building infrastructure for development and institutions for governance. During this phase the officers of Audit and Accounts, Railways and Indian Political Service (IPS) dominated the national economic and political decision-making processes while the political leaders found it difficult to develop any consensus on a framework for developing a political system. During this phase of our history, the CSP chose to play an indirect role in politics. In the process they consolidated their cadre, built their image and reputation as relatively honest, efficient and dedicated civil servants. Unlike the army, the CSP, 'did not take any direct action to subvert the political activity' as the real power holders in the administrative set up. They did not challenge the politicians, rather left it to the military, to confront and replace the facade of parliament in Pakistan. Yet the military elites perceived the CSP as the real power holders and aimed to restrict their role. 


\section{THE RISE AND FALL OF THE CSP 1958-1971}

The military regime under General Ayub Khan provided a challenge and an opportunity to the CSP. The challenge was that initially the military held the CSP as partly responsible for creating political chaos in the country: Therefore they applied pressure on the CSP cadre to mend its ways. In the first instance the military appointed about 272 armed forces officers to important administrative positions in the civil service. In the early 1959, it charged that 13 CSP officers had indulged in "corruption, misconduct, and inefficiency". After a summary trial the regime forcibly retired the officers. This shook the confidence of the CSP cadre. [Burki (1969)]. The military regime demonstrated that it meant business and would purge the CSP, if they did not mend their ways. Thirdly, in August 1959, the regime appointed a Pay and Service Commission, which was headed by A. R. Cornellius, the Chief Justice of Supreme Court of Pakistan, who was known for his anti-CSP views. By such measures the regime conveyed the impression that it aimed to reorganise and restructure the services which implied eroding the power and privileges of the CSP. The CSP were able to resist the challenge that the military regime posed. The CSP showed pragmatism, flexibility and a certain degree of esprit de corps to reach an understanding and compromise with the military regime. Finally, in the same year an Economic Pool was created to manage the senior positions in the Ministry of Finance, Commerce and Economic Affairs. 40 percent of the pool's positions were to be filled by non-CSP officers. The CSP perceived it as yet another effort to undermine their position, as previously these positions were totally reserved for the CSP.

According to the changing needs of the country, the Establishment Division, devised a policy that starting from 1959, all CSP officers will be provided training in fields pertaining to Economics, Public Administration, Community Development, Finance, Accounting etc. Resultantly, by 1968, about 79 CSP officers had obtained training in 17 American and British universities [Burki (1969)]. Braibanti records that the Ford Foundation and USAID played a major role in building training institutions and providing fellowships for the civil servants [Braibanti (1966)]. By changing the direction of training to new fields, the Establishment Division was able to not only strengthen the status of the CSP cadre, but also equipped a generation of civil servants who could lay claim on professional expertise in financial management, community development and good governance.

This new breed of civil servants, enthusiastically supported the two programmes of the military regime, the Basic Democracies and Rural Development Programme. Both these programmes, enormously increased the power, privilege, prestige of the CSP cadre officers, who served in the districts. It also increased their interaction with the local politicians. Consequently, although the district officer was able to promote some sort of community development and welfare, yet as a cadre the CSP ran into conflict with the politicians. In the rural setting of Pakistan, the 
politicians perceived them as 'political manipulators' and 'instruments' of the military regime.

Thus by conceding entry of the military officers to the CSP cadre, reformulation of training programmes, and by enthusiastically supporting the policies of the military regime, the CSP were able to protect their elite status. The cadre was skillful in resisting and subverting the onslaught of Cornellius Commission report and its recommendations. But in the aftermath of Ayub's fall the CSP could not retain their power and glory. Their reputation was tarnished and their confidence was shaken.

\section{CAUSES OF 1973 REFORM}

Whereas the need for reform had been long felt, the immediate causes of the 1973 reforms can be analysed by focusing on the following three factors: student disturbances of 1968-69, dismemberment of the country, rise of the PPP to power.

1. The student protest of 1968-69 which developed into a mass movement, leading to the collapse of Ayub government in March 1969 also targetted the bureaucracy, in particular the CSP. [Ahmad (1974)]. It was the structure and attitude of the CSP that was bitterly attacked and criticised from within the services as well as from the public in general. The CSP-bashing became a persistent theme in the print media and public speeches in 1969. On the 2nd of December 1969 it culminated in the form of Martial Law Ordinance No. 58 by President Yahya Khan. As a consequence of this Order, 303 Class-I Officers were removed from the service. Most of them were senior civil servants; 38 were from the CSP and 78 were from the Central Superior Services. This considerably undermined the power and prestige of the CSP. It is interesting to note that this measure of Yahya Khan was widely acclaimed by the media and opinion-makers of the country. Yahya Khan was seen and portrayed as a leader who was trying to eliminate the corrupt officers of the Civil Services.

2. The Indo-Pakistan conflict of 1971 leading to dismemberment of Pakistan further undermined the position of the bureaucracy in Pakistan. The CSP were further weakened as a cadre because 89 Bengali CSP officers holding posts above Deputy Secretary level (28 of whom were Joint Secretary or above), after the dismemberment of Pakistan opted for Bangladesh. Thus considerably reducing the influence of the CSP as a cadre [Kennedy (1987)]. Secondly, the media and the opinion-makers held the CSP in particular and the bureaucracy in general for the dismemberment of Pakistan. It was believed and argued that the policies made by the CSP had led to the dismemberment of the country.

3. The electoral victory of the PPP in West Pakistan and the kind of attack on bureaucracy that Bhutto and his party started during the anti-Ayub 
movement emerged as an important contributory factor. It is worth noting that in the PPP there were a number of left-leaning urban professionals who advocated that the Civil Services of Pakistan needed a reform. They also believed that the CSP were arrogant and anti-people. In public meetings Bhutto and his party stalwarts termed them as "Noker Shahi", "Brahmins" and "Bara Sahibs".

Bhutto having served in Ayub's government (1958-1966) was aware of the power and organisational capacity of the bureaucracy and was determined to reduce their power. Thus it can be stated that a combination of personal motive and the need for reform on the part of PPP and its leadership provided the context for introducing the 1973 reforms. The 1973 reforms were a radical departure from the established order.

\section{IMPACT OF 1973 REFORMS}

The 1973 administrative reforms although formulated in haste and never implemented in entirety, considerably reshaped the structure of the services and influenced the attitude formation, conduct and legal status of the civil servants (removal of constitutional guarantees). The impact of the reforms was as follows:

1. The CSP, the Lineal descendant of ICS, was abolished. Its members were regrouped into the newly created District Management Group (DMG), Tribal Administration Group (TAG) and the Secretariat Group. Although in 1981 the DMG and TAG were merged as one group.

2. The long standing practice of reservation of posts in the top Secretariat positions for the CSP was discontinued. As a result of All Pakistan Unified Grade System the distinction between CSP, PSP and others was ended.

3. The various groups like Pakistan Audit and Accounts (PAAS), Pakistan Military Accounts (PMAS), Pakistan Railway Accounts (PRAS) were all merged into the Accounts Group.

The 1973 Administrative Reforms, although radical were, not very well conceived nor sufficient effort was made to sustain the alternative that was to emerge as a consequence of reform. The reforms were wide ranging than is generally realised. They have considerably altered the structure of the services and promoted the notion of equality among them. But they did not sufficiently emphasise the need of efficiency, accountability and transparency in performance. However, they did make the federal services more open, competitive and, at least, theoretically provided equality of opportunity to all CSS services.

One of the salient features of the 1973 reforms that is not given adequate attention is that it opened up the DMG, Customs and Foreign Service cadres to women. The Police Service continues to be an exception to the rule. Though in one recent case the widow of a police officer Killed on duty was inducted into the 
service. Now since, 1973, each year depending on the size of recruitment in the CSS i.e. 150 to 200,5 to 25 women have been joining the twelve federal services through the CSS: The average would vary between 5 to 10 percent of the total intake. These women compete on open merit with no reservation of seats, or quotas for women. Thus women who join the services are competitive, dynamic and despite difficulties make a difference in the work environment.

The institution of Common Training Programme (CTP) has considerably tarnished the glory that the CSP had because of exclusivity of training, reservation of posts, differentiation of pay scales, etc. Training has made the service structure relatively open, competitive, egalitarian and amorphous. However, the mystique of CSP as the superior cadre still persists. Quite contrary to the popular perception that a larger number of fresh entrants prefer to join the Customs or Income Tax groups, preliminary estimates from 1987 to 1997 reveal that almost 97 percent fresh entrants write DMG as their first preference, followed by Police, Customs and Excise and for the fourth place Income Tax, Accounts and Foreign Service are in constant competition. (See Table 3) It is interesting to note that despite purges and reforms the 'mystique' of the CSP lingers on. DMG is perceived as the successor to CSP by the new entrants as well as public and other interested groups. A combination of intangible factors, the fascination, myth, perceptions about district, belief in prospects of promotion, continue to attract the new entrants to opt for DMG. Preference patterns reveal that in opting for an occupational group, candidates are still driven by considerations of power, authority, prestige, status, etc. although the occupational groups (Customs and Income Tax) that rouse hopes for financial profit

Table 3

Under Training Officers Preference of Service Groups in Order of Ranking from 1 to 12 1987-1997

\begin{tabular}{|c|c|c|}
\hline & & \% Wise Rankin \\
\hline $\begin{array}{l}\text { Category I: Most Preferred Groups } \\
\text { Ranking: Top Most }\end{array}$ & DMG & $97 \%$ \\
\hline $\begin{array}{l}\text { Category II: 2nd Most Preferred Groups } \\
\text { Ranking: } 2-4\end{array}$ & $\begin{array}{l}\text { Police Customs } \\
\text { and Excise } \\
\text { Income Tax }\end{array}$ & $85 \%$ to $95 \%$ \\
\hline $\begin{array}{l}\text { Category III: Preferred Groups } \\
\text { Ranking 4-8 }\end{array}$ & $\begin{array}{l}\text { Foreign Service, } \\
\text { Audit and } \\
\text { Accounts, CAT }\end{array}$ & $60 \%$ to $80 \%$ \\
\hline $\begin{array}{l}\text { Category IV: Less Preferred Groups } \\
\text { Rankings: 8-12 }\end{array}$ & $\begin{array}{l}\text { OMG, } \\
\text { Information, } \\
\text { Postal Railways } \\
\text { MLC }\end{array}$ & $80 \%$ to $99 \%$ \\
\hline
\end{tabular}

DMG $=$ District Management Group.

$\mathrm{CAT}=$ Customs and Trade.

MLC $=$ Military Lands and Cantonments. 
are gaining salience. The Foreign Service and Accounts groups seem to have fallen in the candidates' scale.

\section{TRAINING AND CAREER PLANNING}

Training and career planning are essential for an efficient bureaucracy. In 1961 the government initiated an administration policy. In pursuance of this policy the Pakistan Administrative Staff College and National Institute of Public Administration were established in Lahore. Simultaneously the discipline of Public Administration was also introduced as a Master's degree programme at the Punjab University. The thrust was to build training institutions and to prepare the civil servants as good, efficient, administrators and policy-makers. However, the initiative was lost early, as no effort was made to train the trainers for the training institutions. Nor did the Establishment Division formulate any policy to link training with career advancement and vertical mobility of the civil servants. Therefore those who joined the training institutions as "some sort of professionals" and those civil servants who were posted in the training institutions as 'deputationists', never really had their 'heart and soul' in training. The trainers at the training institutions developed into a disgruntled lot because they did not have any cadre system. They were and remain uncertain about their career advancement and prospects in the training institutions. The civil servants in general have accepted a posting at the training institutions with reluctance and hesitation. Rightly so, because posting at the training institutions is considered neither meritorious, nor has a good reflection on a civil servant's career prospects.

Unless training institutions are given the status that they deserve they would remain a temporary sanctuary for 'out of favour' officers. This would continue to happen the civil servants recognise that training is a long term investment in human resource development. Without professionally competent and motivated trainers, training would remain an exercise in futility. As we approach the year 2000, once again the FPSC, the Establishment Division, the controlling ministries, the training institutions and on top of all, the political leadership in the country, have to think of evolving a national training policy, which would prepare the Civil Services of Pakistan to deal with the complex issues of governance.

The year 2010 will mark the end of an era, when all those who joined the service, prior to 1973, would have retired, but to steer the course of action for the

21st century, a decision for the creation and sustenance of a policy-making group will have to be made during this decade.

\section{DEMOCRATISATION AND THE CRISIS OF GOVERNANCE}

One of the major consequences of democratisation, particularly since 1988 has been that each regime change is followed by large scale postings and transfers of 
civil servants both at the policy-making level as well as at the district administration level. Resultantly, the civil services have become politicised and the concept of a neutral, upright, citizen friendly public servant has been considerably compromised. Political leaders and political parties forming a government need to take into cognisance that governance cannot improve without developing consensus on the desirability of an efficient, professionally competent, merit driven and non-partisan civil service. For good governance political support and political commitment is a prerequisite.

There are three challenges that have emerged as a consequence of the global trend towards democratisation, privatisation, and internationalisation of world economy. The Civil Services of Pakistan are confronted with how to combat these challenges. The first major challenge is how to adapt and operate in a quasi democratic set up? In Pakistan the transition to democracy is taking place, but the rules and the spirit of democracy is being violated blatantly. Democracy implies government by law, besides electoral competition, majority rule and respect for minority rights and dissent. The challenge for the Civil Services is to provide an anchor for democratic consolidation. Civil Services reflect continuity of policies. Irrespective of who assumes political control, their job is to minimise conflict on policies, develop consensus and ensure continuity. Given their education, training, social background, they can play a pivotal role in strengthening democratic institutions. For the past two decades, conflict among the political leadership has polarised the Pakistani society. This polarisation has affected almost all segments of civil society. The challenge for the Civil Services as an institution is-how to diffuse this polarisation?

Good governance has two dimensions: Political and technical. The Political component demands respect for law, acceptance of the rules of the game. More importantly what is needed is commitment among political leaders to build consensus through bargaining, negotiations and resolution of conflicts through nonviolent means. Simultaneously we have to build and expand the independent press, judiciary and parliamentary institutions. The technical component implies an efficient, competent, corruption free, honest, professionally trained civil service. The technical component demands training, career planning, acquisition of management techniques and new skills by the civil services to enable them to perform the functions of general welfare and national development.

A third salient trend of the recent time is the great increase in violence, that undermines legitimacy of authority, polarises society and puts stress on the efficient functioning of state authority. In most cases it enhances police functions of the state, which in return has given a new twist to interaction among the district administration, police and politicians. Consequently, criminalisation of politics is an alarming trend in Pakistan. In addition politics of patronage and utilisation of state resources for political purposes has led to a situation where a district administration, 
police-politician nexus is emerging as a salient characteristic of Pakistani politics. This nexus if allowed to grow at the current rate, would result in the formation of "Crime cartels" that have been witnessed in Latin America.

The future of democracy and the consolidation of democratic institutions in the country depends not only on political parties but also on the civil servants in their ability to rouse trust and confidence of the people through professionally competent and honest management of the day-to-day business of the state in the service of the people and the country.

\section{GUIDELINES FOR CIVIL SERVICE REFORM}

In the light of foregoing analysis, following policy choices are recommended as broad guidelines for Civil Service reform—a reform that may lead to effective and humane governance.

\section{BUREAUCRAT, PROFESSIONAL, ACADEMIA PARTNERSHIP}

There is a need to evolve a balance between generalist practice and demands of professionalisation. In top policy positions the leadership of the generalist may be retained but professional's advice and input must be encouraged and incorporated in the policy process. Twenty five years ago a Pakistani scholar making pioneer study of Civil Services perceptively suggested that "key posts" in government may be assigned to "generalist-specialist' - someone with "sustained practical experience in a single, well defined, broad area of government activity ... who displays special aptitude for general management” [Ahmad (1964)]. Partnership between bureaucrats, professionals, academic community on policy issues should be encouraged. It must be recognised that internal changes in Pakistani society and external environment have considerably weakened the monopoly of bureaucratic control on information and resources. Bureaucracies now need professional input for project formulation, project implementation and effective management. It demands a change in attitude and re-definition of their role. Since bureaucracies play a pivotal role in policy formulation, and development administration, therefore it is in their institutional interest to work for such a change. To strengthen processes that strengthen good governance, the bureaucracy needs to provide leadership in promoting a partnership among bureaucrats, professionals and academic community.

\section{PREDICTABLE DECISION-MAKING}

Extra-constitutional pressures can be avoided through strong and effective institutions, which demand upholding of rules and procedures that are simple, clear and fair. This would require consultation among political leaders, parliamentarians and the various agencies and departments of the government that must be routinised. What is needed is decision-making process that is not only transparent but also 
reflects consensus and continuity of policies. It requires initiation of such steps: (a) Office manuals (OMs) be prepared about each activity. (b) Detailed Job description be prepared for each post and quantifiable parameters be defined. (c) Criteria for periodical performance evaluations be prepared relevant to the jobs. (d) Feedbacks be obtained from concerned staff and also from institutionalised clients/interactive NGOs etc.

\section{TRAINING; DEVELOPING PROFESSIONAL SKILLS AND ENCOURAGING ATTITUDINAL CHANGE}

Merit alone should be the principal criteria for recruitment in public bureaucracy. Training must be regular and conducted at all levels. Training must be valued and the purposes and philosophy of training must be re-defined. Training should enhance professional skills and raise level of motivation for public service. It should also aim to bring about moral, ethical and attitudinal change in the public servant so that the perception of government from being a "patron" changes to that of a constitutional government. Training of the subordinate staff has been a neglected area for too long. One of the serious failures of higher bureaucracy has been its inability to regulate, control, monitor and evaluate the conduct and behaviour of subordinate staff. This demands a three pronged approach: (1) Develop transparent procedures of recruitment. In recruitment process recognised and effective NGO's representatives be allowed to observe proceedings especially interviews. (2) Effective supervision that improves skills and conduct of the subordinate staff. (3) Training to enhance the quality of services rendered to the general public.

\section{STRENGTHENING POLICY LEVEL AND THE FEDERAL SECRETARIAT}

The 1973 Administrative reforms did facilitate integration among the twelve federal services. They also ensured equality of pay scales among all groups/services. However these reforms did not provide a clear vision and framework for equal opportunity and prospect of promotion for all groups. This has generated rivalry among the services which dominate the federal secretariat and in the process has affected the policy-making process. It merits attention that a federal secretariat devoid of federal spirit and character could increasingly become a burden rather than asset for the federation. Therefore, there is a need to frame rules and procedures for the senior positions, where merit, performance, ability to take decisions to innovate is given weightage and not simply seniority or belonging to a particular service group assigned on the basis of CSS examination.

The bureaucracy in Pakistan is not a monolith. It is divided into a number of groups/services that are constantly engaged in a struggle for supremacy. Each group/service is a functional entity. The CSP/DMG is both perceived and considered 
as the actual elite service: it is envied and emulated. This elite group has continued to maintain dominance on positions of strategic decision-making in the secretariat and at the district level. It is the Federal Secretariat which is becoming an arena of competition and rivalry among services-because control over the Secretariat means control over policy-making and the federal government. Ironically despite this inside rivalry, in public perception the bureaucracy is seen as a monolith, gigantic and united to rule, exploit and perpetuate the status quo. Yet deep down these groups are inter-dependant and viz-à-viz other public institutions they show a tendency to band together.

The workings, orientation and culture of each of these functional groups varies. The dynamics of work, growth and prospects of vertical mobility are also different. However, procedures, slow pace, reluctance to take initiative and general apathy towards citizens' welfare is a malaise from which the entire Pakistani bureaucracy suffers.

The federal secretariat as a policy-making organisation needs to be strengthened. Theoretically, at the Deputy Secretary level, the secretariat is open to all services. But officers are reluctant to join because comparatively they have more facilities and perks in the provincial governments. It would be beneficial if the talent from all government departments is allowed to join the secretariat through a fair and transparent competitive selection process. Besides other quantifiable considerations, open competitive examination be conducted to induct people in the federal secretariat (a classic example is of the Commercial Councillors recently. Only a few privileged knew about the examination and were selected for postings outside). Posts be reserved in each grade (out of the total) for each service group in Federal Secretariat. The criteria for selection should be professional expertise, diversity of experience, demonstrable leadership performance in public institutions; capacity to innovate and accept challenging assignments.

It should be the right of every democratically elected government to appoint persons of its choice in top policy-making positions. These persons could be appointed from within or outside the bureaucracy on a three to four year contract being performance based. What is being suggested is that once these appointments are made they be allowed to act without interference and according to the rules.

\section{FREEDOM OF ACCESS TO INFORMATION}

There is a need to devise rules and procedures for freedom of access to information. Currently, bureaucracy thrives on withholding information under the garb of secrecy. Information on any-area of public concern (Including Customs, FIRs (I.Tax) but its intra-working decisions also (e.g. budgetary grants, expenditures, employee promotions, disciplinary actions etc.) must be available to citizens. The government may levy a token fees for this purpose, but information must be available readily. The freedom of access to information could make public 
transactions transparent, it will minimise the usage of discretionary powers if any, and would make the bureaucracy conscious of accountability. Once the civil servants realise that any information from government can be obtained in public interest, swiftly and at a small financial cost, their ability to use discretionary laws would be restricted. Then discretion would be used only for public good and public welfare and not against public interest.

\section{RECASTING THE IMAGE OF THE CIVIL SERVANT}

Civil Servants as enforcers of rule of law and implementers of policy are expected to act as conscience of the society. Ideally they must be guided by what is in the best interest of the citizens, and not of a particular person, political party or a group. In Pakistani society, there is a growing gap between the self-image of a civil servant - that he is achiever, holds authority, power and possesses superior intellect, and that this has been demonstrated by the success in the competitive examination. This self-image keeps the civil servant beholden to power and encourages detachment. Then there is a public image of the civil servant—which is that the civil servant is arrogant, aloof, authoritarian, corrupt, symbolising coercion and injustice. Over the years this gap between the self-image and the public perception has widened. This has put tremendous pressure on the civil servant and public scrutiny has become harsher. Thus the onus of responsibility is on the civil servants to alter this image. They need to project and perform not as rulers but as servants of the public. Similarly the public advocates also need to re-look at the role of civil servants, a little more objectively and specific to situations. In a culture where familiarity encourages influence peddling, it becomes desirable that in public interest and to impart justice and fairness, the civil servant may remain detached from showing preference for one or other group. Impartiality, fairness, adjudication of justice through transparency need to become the guiding principles of the bureaucrat.

\section{ATTRACTIVE SALARY PACKAGE}

To make public service attractive two conditions are essential. First, restore the pride in public service by promoting merit and performance and by eliminating safarish and patronage. It is difficult but not impossible. Second, provide an attractive salary package-a package that has some semblance of proportion between the elite status of the higher civil services (CSS Services), and the powers of authority that are vested in them. One is not advocating a salary structure comparable to private sector but a salary package that is competitive and encourages honesty and integrity among the public officials. There should be salary/pay scales with regular increments and then bonus increments to those who show excellent performance over the last year. This should not be awarded on just the superiors' evaluation but on formal feedback of subordinates, evaluation of quantifiable work output and also 
weighing in some cases on the recommendations of established NGOs/concerned public. Similar promotions to each grade especially from grade 17 onwards be not just on the number of years put in and on vacancies but also on other factors (on the basis as described above).

A formal feedback from subordinates, which is given some weightage in the evaluation of the superior himself is necessary. This step would also give subordinate staff confidence and would thus make CSS officer less overbearing. Individual integrity is a desirable goal but institutional integrity is imperative.

\section{DECENTRALISATION AND DEVOLUTION OF POWER}

There is no gainsaying the fact that financial and administrative powers of the provinces need to be enhanced. However there is need to build and strengthen the local bodies institutions. Community participation would grow and expand if we began to streamline structures at the district and tehsil levels. At these levels the role of district administration needs to be redirected from that of a patron to being an equal partner-a complementarity between the district administration and local bodies-a functional specialisation-where the two interact and strengthen public institutions at the grass root level.

At the local level the functions of councillors and the district administration overlap. Traditionally the distract administration managed the functions of recruitment, development funding/projects and collection of Zila/Tehsil Taxes. The role of district administrator was both advisory and paternal. The powers were concentrated in the district administration. However, with expansion of political participation, democratisation and electoral contestation, demands for devolution of authority have increased. The elected public officials at the local and district level began to demand greater share and control in recruitments, identification and implementation of developmental projects and tax collection. This intensified conflict of interest between the district administrators and local councillors. This conflict has affected governance at the local level. To strength local government institutions, enhancing community participation and devolution of power, it is desirable that power-sharing mechanisms be evolved and strengthened between local public office holders and district administration. Decentralisation has failed-the answer to the problem is devolution of authority.

\section{BUILDING TRUST: REDEFINING SUPERORDINATE- SUBORDINATE RELATIONSHIP}

A recent report by O.E.C.D on changing direction in management correctly notes that: 
Governance reflects a pluralisation of the important actors in governing and in providing public service. The configuration of public institutions is changing; the roles of super- and sub national bodies are becoming more important; and semi-public and private sector actors are becoming more widely and deeply involved.

Thus interaction is becoming less authoritative and more cooperative. This demands an attitudinal change, because compliance through top-down orders alone is becoming increasingly difficult. A public official's skills to persuade colleagues and motivate the staff to accomplish a task is gaining weightage. This demands building a relationship of trust, confidence and credibility between a public official as the leader and a subordinate as a functionary of the government.

Doors to higher position should also be made easier for subordinate staff, so that they too have a stake in the system to work honestly and effectively.

Parallel Groups be created whose only job would be to address the problems being confronted by the public (these parallel bodies are already in place but are manned by their respective groups e.g. redressal from Income Tax is before I.Tax Appellate Tribunal, etc. These invariably support their Peers). They should also include NGO representatives if possible. Press may also be allowed participation.

These parallel institutions should also prepare periodical reports on the functioning of the above and give it to press.

Detailed transparency documents of the functioning of each department/major formations be prepared (by inviting people of diverse background and interest groups) for example, PWD, I.Tax, NHA, CAA etc. These documents called office manuals would replace the existing ambiguous subjective office procedures.

Financial Rules be drawn anew and be made easy and simple (e.g. now officials have different powers to purchase the same thing under different grants/heads of expenditure) Financial Rules are so complex (for the same reason they are flouted than observed) that even a CSS officer of 25-30 years of experience is ignorant about these and more often than not needs a shrewed person from the subordinate staff to handle the purchase.

Thus the premium is on the personal traits, performance, reputation and professional skills of the individual officer. Upon his commitment, credibility, persuasive skills and professional expertise depends the performance of the staff. Credibility and performance of public institutions is dependant on the quality of manpower. If the quality of manpower declines, the decay of public institutions follows. To arrest the decay of public institutions one needs to invest in the human capital-the focus has to be strengthening personal integrity and professional expertise of the manpower. 


\section{CONCLUSION}

From the review of literature, changing socioeconomic profile and attitude formulation among the federal bureaucrats we can conclude that despite limitations, the elite status and staying power of the bureaucracy is generally recognised, this is particularly more pronounced in Pakistan. Here again like most of the Third World states signs of erosion are visible. Bureaucratic institutions are certainly in a disarray if not in decline. There are two options available: first, a radical restructuring of the existing bureaucratic order. Secondly, a piece-meal but holistic reform of the existing bureaucratic institutions. In this paper, I have opted for the second option, and provided guide lines for a piece-meal reform in a broad set of areas. An effort has been made to analyse the framework of bureaucratic order and identify areas where reform is urgently needed. To arrest the process of decay in the bureaucratic institutions and to make a turnaround, a partnership among professionals, bureaucrats and academia is a desirable goal for building an environment and framework for reform. Secondly, to bring about an attitudinal change and improve the skills of civil servants, strengthening of training institutions is a must. Thirdly, devolution of power in the districts and redefining the power structure of the federal secretariat is essential. Fourthly, the salary package for the civil servant is out of tune with financial realities, it needs a drastic revision, if we aim to reduce corruption, injustice and improve the efficiency of the public servant. Fifth, most importantly, political leadership and bureaucracy need to develop a transparent and effective partnership for promoting public interest and ensuring humane governance. An adversarial relationship between the two or an interlocking to protect the vested interest of privileged groups only, would mar the growth of robust institutions, undermine effective governance and consolidation of democracy. Finally it must be understood and appreciated that civil service is a profession where one is expected to work for the welfare of the fellow citizens, it is not simply managerial professionalism, it has a ethical and human dimension-welfare of the fellow citizens.

\section{REFERENCES}

Ahmad, Muneer (1964) Civil Servant in Pakistan. Karachi: Oxford University Press.

Ahmad, Muneer (1974) Political Sociology; Perspectives on Pakistan. Lahore: Punjabi Adabi Markaz.

Apter, David (1967) Politics of Modernisation. Chicago: University Press of Chicago.

Boeninger, Edgardo (1991) Governance and Development: Issues and Constraints. In Proceedings of the World Bank Annual Conference on Development: Economics. The World Bank. 267-288.

Braibanti, Ralph (1966) Research on the Bureaucracy of Pakistan: A Critique of Sources and Issues. Durham, N.C.: Duke University Press. 
Burki, Shahid Javed (1968) A Historical Perspective on Development. In Shahid Javed Burki and Robert Laporte Jr. (eds) Pakistan's Development Priorities: Choices for the Future. Karachi: Oxford University Press. 15-44.

Burki, Shahid Javed (1969) Twenty Five Years of the Civil Service in Pakistan: A Reevaluation. Asian Survey 9:4 239-254.

Burki, Shahid Javed, and Robert Laporte Jr. (eds) (1986) Pakistan's Development Priorities: Choices for the Future. Karachi: Oxford University Press.

Drucker, Peter (1998) In Defence of Japan's Bureaucracy. Foreign Affairs 77:5 250253.

Hulme, David (1997) Governance, Administration and Development: Making the State Work. London: Macmillan Press. 105-131.

Huntington, Samuel P. (1968) Political Order in Changing Societies. New Haven: Yale University Press. 250-253.

Kennedy, Charles (1987) Bureaucracy in Pakistan. Karachi: Oxford University Press.

Lapalambora, Joseph (1963) Bureaucracy and Political Development. Princeton: Princeton University Press.

Laporte Jr, Robert (1975) Power and Privilege: Influence and Decision Making in Pakistan. Berkeley: University of California Press.

Martin, Dennis Constant (1991) The Cultural Dimensions of Governance. In Proceedings of the World Bank Annual Conference on Development, Economics, Washington, The World Bank. 325-342.

Mufti, Masud (n.d.) A retired former Civil Servant who frequently writes in Dawn on the decline and decay of Civil Services in Pakistan.

O, Donell, Gulimero (1973) Modernisation and Bureaucratic Authoritarianism: Studies in South America Politics, Politics of Modernisation. Berkeley, Institute of International Studies, University of California Press. (Series No. 9.)

O.E.C.D. (1997) Organisation for Economic Cooperation and Development, Managing Across Levels of Development, Paris, OECD. 15-16.

Osborne, and Ted Baebler (1993) Reinventing Government: How the Entrepreneurial Spirit is Transforming the Public Sector. New York: Penguin, Palme.

Osborne, David Plastrick (1996) and Banishing Bureaucracy: The Five Plastrick, Peter Strategies for Reinventing Government. Reading, (M.A) Addison - Wesley.

Pakistan, Government of (1962) Report of the Pay and Services Commission: 19591962. Karachi.

Siddique, Tasneem, Has been associatd with Hyderabad Kachi Abadi Scheme and has written in Dawn on the decline of Public Service in Pakistan.

Vorys, Karl Von 1965 Political Development in Pakistan, Princeton, Princeton University Press.

World Bank (1983) World Bank Report. Washington, D. C.

World Bank (1985) World Bank Report. Washington, D. C.

World Bank (1993) World Bank Report. Washington, D. C.

World Bank (1997) World Bank Report. Washington, D. C. 